\title{
The food value of biltong (South African dried meat) and its use on expeditions
}

\author{
By H. E. LEWIS* AND J. P. MASTERTON \\ (British North Greenland Expedition), Division of Human Physiology, \\ National Institute for Medical Research, Holly Hill, London, N.W. 3 \\ AND P. G. WARD \\ Human Nutrition Research Unit, Nutrition Building, National Institute for Medical \\ Research, The Ridgeway, Mill Hill, London, N.W. 7 \\ (Received 8 May 1956--Revised 25 September 1956)
}

Biltong is a traditional South African preparation of the meat of game, salted and dried in the sun. It can be eaten without further preparation, and pieces can conveniently be carried in the pocket. It occurred to one of us (H.E.L.), who is a South African, that biltong might be a useful addition to the sledging rations on the British North Greenland Expedition (Lewis \& Masterton, I955 $a, b$ ), and an approach for a supply was made to the Rhodesian Government through its High Commissioner in London.

We were extremely grateful for their generous gift of $\mathrm{I}$ cwt. of biltong. It was prepared from the carcasses of three antelopes, the shooting of which required special permission as it was the close season, and since time was so limited the donors showed even further imagination by sending the gift air-freight by Comet from Rhodesia so as to reach the expedition ship before it left on 8 July 1952 .

A month later it was unpacked at the Expedition main base, Britannia Sø in North East Greenland, and pieces were distributed to the men sledging to the interior of the ice sheet to set up the Northice weather station at latitude of about $80^{\circ} \mathrm{N}$.

Biltong, in South Africa, is a national delicacy, but outside the subcontinent it is relatively unknown. Its taste usually requires some cultivation, especially as the dried meat has an unappetizing appearance not unlike that of a piece of dark wood. It is quite hard, but it is softened readily by the saliva when it is chewed. However, on the British North Greenland Expedition it was appreciated and enjoyed by almost all the members when they ate it as a snack during sledging or man-packing. In view of its acceptability this investigation was carried out to find the value of biltong to travellers, whether in polar regions or elsewhere, on either big or small expeditions.

\section{Historical}

The origin of the word is obscure but probably derives from early Afrikaans, bil referring to the hindquarters of an animal, and tong to a fillet (cf. 'tongue').

Biltong has been known for centuries in Southern Africa, having been used by

* Formerly Lecturer in Physiology, University College London. 
nomadic people and pioneer trekkers. A similar product is known in Switzerland, in Norway and in the North American Arctic where it was the original pemmican. and is prepared from indigenous animals like the caribou. The word pemmican now refers generically to any mixture of meat and fat concentrates. In Mongolia driedpreserved meat is part of the winter diet; it is softened by soaking before cooking (Montague, 1955).

As a practical method of meat preservation and storage, biltong was particularly valuable to Boer Commandos during the South African war, for, with the addition of dried fruit to their diet, they were able to stay out in the field, independent of lines of supply for many weeks.

\section{Preparation}

The best biltong comes from the meat of freshly killed herbivorous animals of the antelope and bovine families. The smaller animals-duiker, springbok and kuduprovide the finer meat, which gets progressively coarser in larger animals like the eland, sable antelope and, finally, the ox or steer.

The best cuts are the loin immediately behind the kidneys, dorsal muscles on each side of the spine and the haunches. The meat should be cut lengthwise, i.e. along the line of the muscle fibres. In this way it is possible to isolate complete biltongs by making the separation coincide with the line of the intermuscular septa. A number of long pieces of meat, varying from $\mathrm{I}$ to $2 \mathrm{ft}$. in length, are obtained and then sliced into strips about 2 in. wide which may be easily handled. The strips are then salted, usually by being drawn through a handful of salt. The tradition of adding spices as well, according to taste, may well date the history of biltong to the Dutch East India Company's spice trade of the seventeenth century. After salting, the strips are dried by hanging, well-spaced, preferably outside in the shade and exposed to the wind although protected from rain, frost and dew. The thinner strips dry more efficiently. Depending on their size, the strips of biltong are ready to eat or store after Io-14 days' hanging.

In South Africa biltong is prepared on the high veld of the interior where the cool, dry winter climate is particularly suitable. The damper coastal areas, such as Cape Town and the subtropical city of Durban, are unsuitable places for its production. Although one cannot prepare biltong in Britain because of the climate, it may be practicable to use other drying techniques.

\section{Composition and food value}

In contrast to meat, which contains $45^{-70} \%$ moisture, depending on the cut and type, and, in addition, bone, fat and other tissue, biltong is completely edible, being made from pure muscle, and when ready for consumption contains $5^{-20} \%$ moisture, according to individual taste. The less dehydrated preparation, which is preferred by many people, has a characteristically different texture and taste from that of the really dry sticks just described.

We have estimated the calorific value of the biltong as well as its composition in respect to nitrogen, water, ash (including sodium chloride), fat and carbohydrate 
('glycogen'). We have not estimated its content of vitamins and other essential minor nutrients but since it is prepared at a low temperature $\left(4-10^{\circ}\right)$ probably no appreciable loss has occurred in biltong compared to the original fresh tissue.

\section{EXPERIMENTAL}

Before analysis random lengths of biltong were cut into small sections of about $\mathrm{I}$ in. cubes and ground in a laboratory mill. The product was a fine buff-coloured powder together with a fibrous residue ( $0.7 \%$ of total material) which was not analysed.

All analyses were carried out on the original sample unless otherwise stated.

(a) Nitrogen. The Kjeldahl-Markham method, described by Kabat \& Mayer (1948), was used.

(b) Water and ash. See Simpson, Chow \& Soh (195 I).

(c) Sodium chloride. Duplicate, weighed $2 \mathrm{~g}$ samples were shaken with about $40 \mathrm{ml}$. distilled water in a centrifuge tube and then spun for $15-30 \mathrm{~min}$ at 2000 r.p.m. (900 g). The supernatant liquid was transferred to a $100 \mathrm{ml}$. volumetric flask and the residue twice re-extracted with $20 \mathrm{ml}$. water and recentrifuged. The washings were added to the initial supernatant liquid and made up to mark. Portions were analysed for chloride by Mohr's method (Vogel, 195I). The residues were dried completely at $105^{\circ}$ and stored.

(d) Water and fat. Duplicate, weighed $7 \mathrm{~g}$ samples were analysed for both water and fat by the simultaneous-extraction method, using di-isopropyl ether, of Kaye, Leibner \& Connor (1940). Allowing for the fundamental differences in technique between the methods used in sections $(b)$ and $(d)$ the agreement on percentage of water is fairly good (see Table $\mathbf{r}$ ) and is supported by later work on fresh muscle and liver.

(e) Carbohydrate ('glycogen') (estimated as glucose). Weighed samples were hydrolysed in $\mathrm{N}-\mathrm{HCl}$ for $2 \frac{1}{2} \mathrm{~h}$ at $100^{\circ}$ and, after filtration, the filtrate was made up to a known volume $\left(25^{\circ} \mathrm{ml}\right.$.). Glucose was estimated in portions of this volume by the method of Hanes (1929), modified by the use of sodium tungstate, as recommended by Blish \& Sandstedt (1933). Polyvinyl alcohol (Miller \& Bracken, I95I) was found to be preferable to starch as an indicator in this estimation.

(f) Calorific value. To find this value use was made both of the bomb calorimeter and of the application of standard factors to the values obtained by analysis (sections $(a)-(e)$ ).

For the calorimetry the standard procedure was used. As one of us (Ward, 1956) had earlier observed that powdered foodstuffs and excreta do not burn satisfactorily, either as pellets or in gelatin capsules, all these samples were burnt under a layer of glycerol. This modification is part of the routine procedure used at the Human Nutrition Research Unit.

The standard factors have been taken from Sherman (1952) for the total combustion, and from McCance \& Widdowson (1946, p. 6) for the 'physiological' calorific values:

$\begin{array}{lcc} & \begin{array}{c}\text { Sherman } \\ \text { (Cal./g) }\end{array} & \begin{array}{c}\text { Modified Rubner } \\ \text { (Cal./g) }\end{array} \\ \text { Carbohydrate (as glucose) } & 4 \cdot 10 & 3 \cdot 75 \\ \text { Fat } & 9 \cdot 45 & 9 \cdot 30 \\ \text { Protein } & 5 \cdot 65 & 4 \cdot 10\end{array}$


(g) Domestic use. To supplement the analyses we have also considered the domestic use after rehydration and we record the following observations:

(I) On soaking a piece at $4^{\circ}$ in excess water it was noted that the water became bloodstained after $\mathrm{I} 2 \mathrm{~h}$ and the meat was then pliable and could be easily shredded. With further soaking at the end of $24 \mathrm{~h}$ it had doubled its volume with a $36 \%$ increase in weight, and $24 \mathrm{~h}$ later the now insipid meat, having lost most of its salt, was $145 \%$ larger than initially and $50 \%$ heavier.

(2) In order to improve its taste a second piece was steeped in excess $5 \% \mathrm{NaCl}$ solution for $45 \mathrm{~h}$ at room temperature $\left(20^{\circ}\right)$ and, after draining, diced and shredded before frying in butter. The soaked meat, before frying, showed an increase of $120 \%$ in weight and was more palatable. This weight increase probably indicates improved rehydration due to the higher temperature, and the meaty taste has been maintained by the prevention of salt diffusion from the meat by the salt concentration in the surrounding water.

When the meat was diced and fried an acceptable steak-like product was obtained, and on frying after shredding the meat is suitable for rissoles and curries. By both treatments a rich gravy was also prepared.

\section{RESUL.TS}

Chemical composition. In Table I the chemical composition of biltong as determined now is compared with that of Bovril pemmican (Widdowson, 1955, personal communication), dehydrated meat bar (Ministry of Agriculture, Fisheries \& Food, 1954, personal communication), and raw beef-steak (McCance \& Widdowson, 1946). From this table it will be noted that, as expected from its preparation, biltong has a high ash and protein content and a low fat and water content when compared with the other 'meats' listed.

Calorific value. Also listed in Table I are the calorific values based on the Sherman and the Rubner factors, as well as those derived experimentally for biltong in the bomb calorimeter. In contrast to the other 'meats' there is a marked difference between its 'total' and physiological calorific value of about roo Cal./roo g.

As shown in Table I, the agreement between the total calorific values obtained in the bomb and by calculation is good as allowance must be made for the Sherman factors being averages over a wide range of foods. In general, agreement is less good between bomb calorific values and those derived from chemical analysis by means of the Rubner factors because the physiological calorific value more truly represents the utilizable energy of the food eaten, and is, as shown, much lower, especially for meat.

Domestic use. We consider that biltong can be readily rehydrated into a meat suitable for frying, and possibly boiling, thereby providing a hot solid meat meal in place of those of a soup-like nature provided by pemmican. A variety of hot meat dishes can be provided therefore from supplies of 'raw' meat, with a reduction of bulk to one-third and of weight by one-third, and the meat may also be used without rehydration, as a cold snack, so increasing the variety in the dietaries of expeditions. 
Table I. Comparison of $(A)$ the percentage chemical composition and $(B)$ the calorific value of biltong with that of some other meats

\begin{tabular}{|c|c|c|c|c|c|c|c|c|}
\hline \multicolumn{9}{|c|}{$\boldsymbol{A}$} \\
\hline Constituent & \multicolumn{2}{|c|}{$\begin{array}{c}\text { Biltong } \\
\text { (this study) }\end{array}$} & \multicolumn{2}{|c|}{$\begin{array}{l}\text { meat bar } \\
\text { (Ministry of } \\
\text { Agriculture, } \\
\text { Fisheries and } \\
\text { Food, I954)* }\end{array}$} & \multicolumn{2}{|c|}{$\begin{array}{c}\text { Pemmican } \\
\text { (Widdowson, } \\
\text { 1955)* }\end{array}$} & \multicolumn{2}{|c|}{$\begin{array}{c}\text { Raw beef-steak } \\
\text { (McCance \& } \\
\text { Widdowson, } \\
\text { r946) }\end{array}$} \\
\hline Water & \multicolumn{2}{|c|}{$11 \cdot 5 \dagger$} & \multicolumn{2}{|c|}{$7 \cdot 5$} & \multicolumn{2}{|c|}{ (by difference) } & \multicolumn{2}{|c|}{$68 \cdot 3$} \\
\hline [Total nitrogen & \multicolumn{2}{|c|}{$10.4 t$} & \multicolumn{2}{|c|}{$7 \cdot 9$} & \multicolumn{2}{|c|}{$6 \cdot I$} & \multicolumn{2}{|c|}{$3 \cdot 2]$} \\
\hline Protein $(\mathrm{N} \% \times 6.25)$ & \multicolumn{2}{|c|}{$65 \cdot 0$} & \multicolumn{2}{|c|}{$49 \cdot 3$} & \multirow{2}{*}{\multicolumn{2}{|c|}{$38 \cdot I$}} & \multicolumn{2}{|c|}{$19 \cdot 3$} \\
\hline Fat & \multicolumn{2}{|c|}{$I \cdot 9$} & \multicolumn{2}{|c|}{$40 \cdot 0$} & & & \multicolumn{2}{|c|}{ 10.5 } \\
\hline Carbohydrate & \multirow{3}{*}{\multicolumn{2}{|c|}{$\begin{array}{l}7 \cdot 5 \\
6 \cdot 8\end{array}$}} & \multirow{2}{*}{\multicolumn{2}{|c|}{ 一 }} & \multirow{2}{*}{\multicolumn{2}{|c|}{ 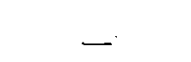 }} & \\
\hline [As glucose & & & & & & & \multicolumn{2}{|c|}{ Nil] } \\
\hline $\begin{array}{l}\text { As glycogen } \\
\text { (glucose } \% \times 0.9 \text { ) }\end{array}$ & & & \multicolumn{2}{|c|}{ - } & \multicolumn{2}{|c|}{ 一 } & \multicolumn{2}{|c|}{-} \\
\hline Ash & \multicolumn{2}{|c|}{$12 \cdot 5 \S$} & \multicolumn{2}{|c|}{$3 \cdot 2 \|$} & \multicolumn{2}{|c|}{14.9} & \multicolumn{2}{|c|}{1.9} \\
\hline Total & \multicolumn{2}{|c|}{$97 \cdot 7$} & & & & & & \\
\hline & & & $B$ & & & & & \\
\hline & $\begin{array}{r}\mathrm{Bi} \\
\text { (this }\end{array}$ & idy) & $\begin{array}{l}\text { Dehy } \\
\text { med } \\
\text { (Min } \\
\text { Agric } \\
\text { Fishe } \\
\text { Food. }\end{array}$ & $\begin{array}{l}\text { rated } \\
\text { bar } \\
\text { ry of } \\
\text { ture, } \\
\text { s and } \\
954)^{*}\end{array}$ & $\begin{array}{r}\text { Pen } \\
\text { (Wid }\end{array}$ & $\begin{array}{l}\text { can } \\
\text { xson, } \\
*\end{array}$ & $\begin{array}{r}\text { Raw b } \\
\text { (McC } \\
\text { Widd }\end{array}$ & $\begin{array}{l}\text {-steak } \\
\text { ce \& } \\
\text { vson, }\end{array}$ \\
\hline & & & & & & & & \\
\hline & $100 \mathrm{~g}$ & oz. & $\begin{array}{l}\text { Cal./ } \\
\text { roo g }\end{array}$ & $\begin{array}{c}\text { Cal./ } \\
\text { oz. }\end{array}$ & $\begin{array}{l}\text { Cal./ } \\
\text { I00 g }\end{array}$ & $\begin{array}{c}\text { Cal./ } \\
\text { oz. }\end{array}$ & $\begin{array}{l}\text { Cal./ } \\
\text { Ioo g }\end{array}$ & $\begin{array}{c}\text { Cal./ } \\
\text { oz. }\end{array}$ \\
\hline Bomb calorimeter & 428 & 121 & - & - & - & - & - & - \\
\hline Total (Sherman) & 416 & II 8 & 657 & 186 & 628 & 178 & 208 & 59 \\
\hline $\begin{array}{l}\text { 'Physiological' } \\
\text { (Rubner) }\end{array}$ & 312 & 88 & 574 & 162 & 560 & I 59 & 178 & 50 \\
\hline
\end{tabular}

* Personal communication. + By method $(b)_{1} I^{\cdot} 5$, by method $(d)$ I0.0. $\ddagger$ Nitrogen content of original sample 10.0, after treatment $(a)$ 10.6. $\$$ Extract (see p. 7) contained 10.0\% $\mathrm{NaCl}$. $\|$ By difference and including trace of carbohydrate.

\section{DISCUSSION}

The objective in planning the commissariat of expeditions is to maintain high-calorie diets rich in protein and fat, in little bulk, and it was for this reason that the synthetic foods 'pemmican' and 'dehydrated meat bar' were developed.

Biltong has a high calorie value lying midway between the synthetic pemmican and raw beef-steak. It is extremely rich in protein and salt (sodium chloride) but very low in fat, which is not surprising as it is prepared from selected lean meat. However, it would be undesirable to have biltong as the sole source of calories in the absence of other high-calorie foods containing fat and carbohydrate; but under normal field conditions adequate supplies of butter and sugar are usually made available. Similarly, because of the high salt content, biltong is not recommended if supplies of drinking water are scarce. Some members of the Expedition commented on the saltiness of the material distributed. As it causes thirst it is a disadvantage when water is not easily obtained, as, for example, on trek in Greenland during the cold season when 
water is available only as snow or ice. However, the salt content of the biltong can easily be controlled during preparation.

Since biltong can be chewed while travelling we suggest it might conveniently replace some of the pemmican or dehydrated meat bar and, as biltong contains little fat, it can be supplemented by the addition of cream cheese to the day's diet.

Table 2 shows how $2 \mathrm{oz}$. of biltong (see Pl. I), 2 oz. cream cheese and half the usual amount of pemmican $(2 \cdot 8 \mathrm{oz}$.) modify the diet to provide slightly more protein, fat, carbohydrate and calories but, most important, a highly acceptable variation, at a cost of only $\mathrm{r} \cdot 2 \mathrm{oz}$. extra weight. This weight is negligible and can be more than offset by intelligent and modern packaging, a matter we propose to discuss in another paper.

In planning the commissariat, potential travellers should use great caution in applying data from food tables. This is true of those who still use the lists published by earlier explorers of this century, in which it is not stated how the final calorie value was derived. Unless this is realized there is a danger of over- or under-estimating the actual utilizable calories, particularly when the diet is protein-rich, since various systems of estimation exist. The difficulties in their correlation have been commented on more fully by many workers, including Morey (1936-7) and Widdowson (1955).

Masterton, Lewis \& Widdowson (1955) noted that husky dogs have a ravenous appetite, but get bored with dog pemmican. A prepared dog-food, as a variation to their diet, was presented to the expedition by manufacturers, but the dogs only touched it as a last resort, and only if margarine was not forthcoming. On one occasion when off their leads, some recently fed dogs stole several pieces of biltong from a supply bag and ate them so eagerly, with great salivation, that we realized that a form of biltong, prepared from horseflesh or a similar cheaper meat, could be introduced advantageously into the dog ration.

We have carried out this investigation in order to ascertain the value of biltong to travellers who are in polar regions or elsewhere and therefore unable to obtain immediate supplies of fresh food.

\section{SUMMARY}

I. Biltong is partially dehydrated, salted, lean meat. Its traditional home is South Africa where it is prepared from the dorsal muscles of herbivorous animals of the antelope and bovine families by wind drying of salted strips. When dry, after some Io days' hanging, the hard strips can be stored indefinitely or chewed.

2. It has been analysed chemically except for vitamins and other essential minor nutriments and, as expected, found to be almost fat-free but containing about $65 \%$ protein and $12.5 \%$ ash. It has a total calorific value of $4 \mathrm{I} 6 \mathrm{Cal} / \mathrm{roo} \mathrm{g}$ (428 Cal./roog by bomb calorimeter) and a physiological calorific value of $312 \mathrm{Cal} / / \mathrm{ro0g}$ due to its high protein content.

3. We have found that biltong can be satisfactorily rehydrated and subsequently cooked.

4. We recommend biltong as a useful addition to expedition dietaries replacing, in part, pemmican. To offset the low fat and high salt and protein content the addition of cream cheese is suggested (see Table 2).

5. It can also be used as a supplement to dog pemmican. 
ฐั

造 =

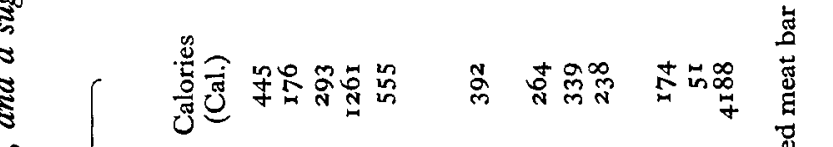

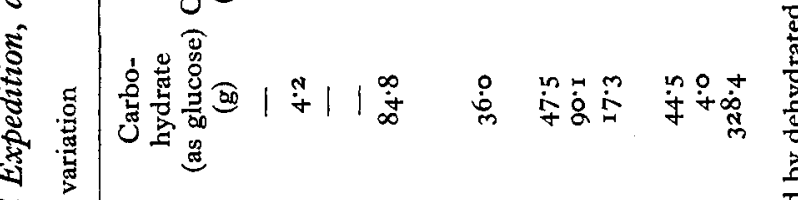

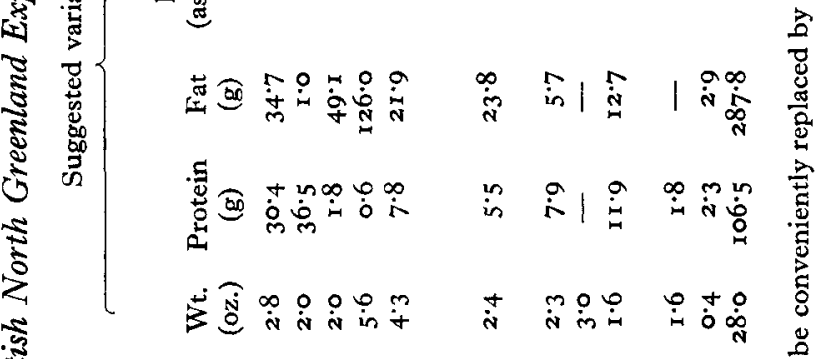

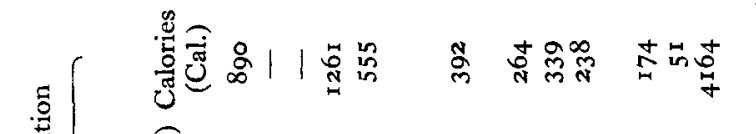

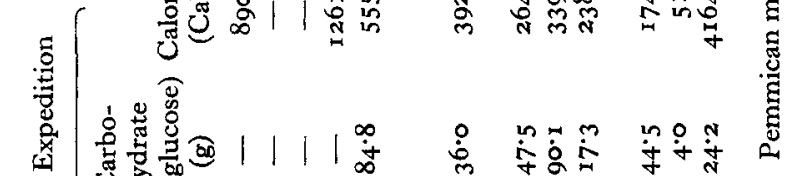

离<smiles>[CH]1C[C@H]2C[C@@H]1C2</smiles> 
The authors are grateful for valuable information from $\mathrm{Dr} A$. W. Lategan, Director of the South African National Nutritional Research Institute, and from Mr H. H. H. Bierman, formerly of South Africa House, London. They wish to thank in particular Professor B. S. Platt, C.M.G., and Dr C. R. C. Heard for advice and facilities in the Human Nutrition Research Unit, Medical Research Council, and also their colleagues on the British North Greenland Expedition $195^{2-4}$ for their co-operation in the field.

\section{REFERENCES}

Blish, M. J. \& Sandstedt, R. M. (1933). Cereal Chem. ro, 189.

Hanes, C. S. (1929). Biochem. Y. 23, 99.

Kabat, E. A. \& Mayer, M. M. (1948). Experimental Immunochemistry, ist ed., p. 282. Springfield, Ill.: Charles C. Thomas.

Kaye, I. A., Leibner, I. W. \& Connor, E. B. (1940). F. biol. Chem. 132, 195.

Lewis, H. E. \& Masterton, J. P. (I955a). Lancet, 269, 494.

Lewis, H. E. \& Masterton, J. P. (1955b). Lancet, 269, 549.

Masterton, J. P., Lewis, H. E. \& Widdowson, E. M. (1955). Proc. Nutr. Soc. 14, xvi.

McCance, R. A. \& Widdowson, E. M. (1946). Spec. Rep. Ser. med. Res. Coun., Lond., no. 235.

Miller, S. A. \& Bracken, A. (1951). F. chem. Soc. p. 1933.

Montague, I. (1955). Geogr. Mag., Lond., 28, I 19.

Morey, N. B. (1936-7). Nutr. Abstr. Rev. 6, I.

Sherman, H. C. (1952). Chemistry of Food and Nutrition, 8th ed., p. 134. New York: The Macmillan Company.

Simpson, I. A., Chow, A. Y. \& Soh, C. C. (195I). Bull. Inst. med. Res. F.M.S. N.S. 5, 7.

Skipsey, W. (1956). Army Energy Expenditure Survey, Division of Human Physiology, Medical Research Council, London (unpublished).

Vogel, I. A. (195I). A Textbook of Quantitative Inorganic Analysis (Theory \& Practice), 2nd ed., pp. 251, 252. London: Longmans Green and Co.

Ward, P. G. ( 1956 ). Unpublished.

Widdowson, E. M. (1955). Proc. Nutr. Soc. I4, 142.

\section{EXPLANATION OF PLATE}

Daily ration of $2 \mathrm{oz}$. biltong. It has been broken into three convenient lengths for keeping in the pocket. It can be eaten without further preparation while travelling. 
H. E. LEWIS, J. P. MASTERTON AND P. G. WARD. Biltong

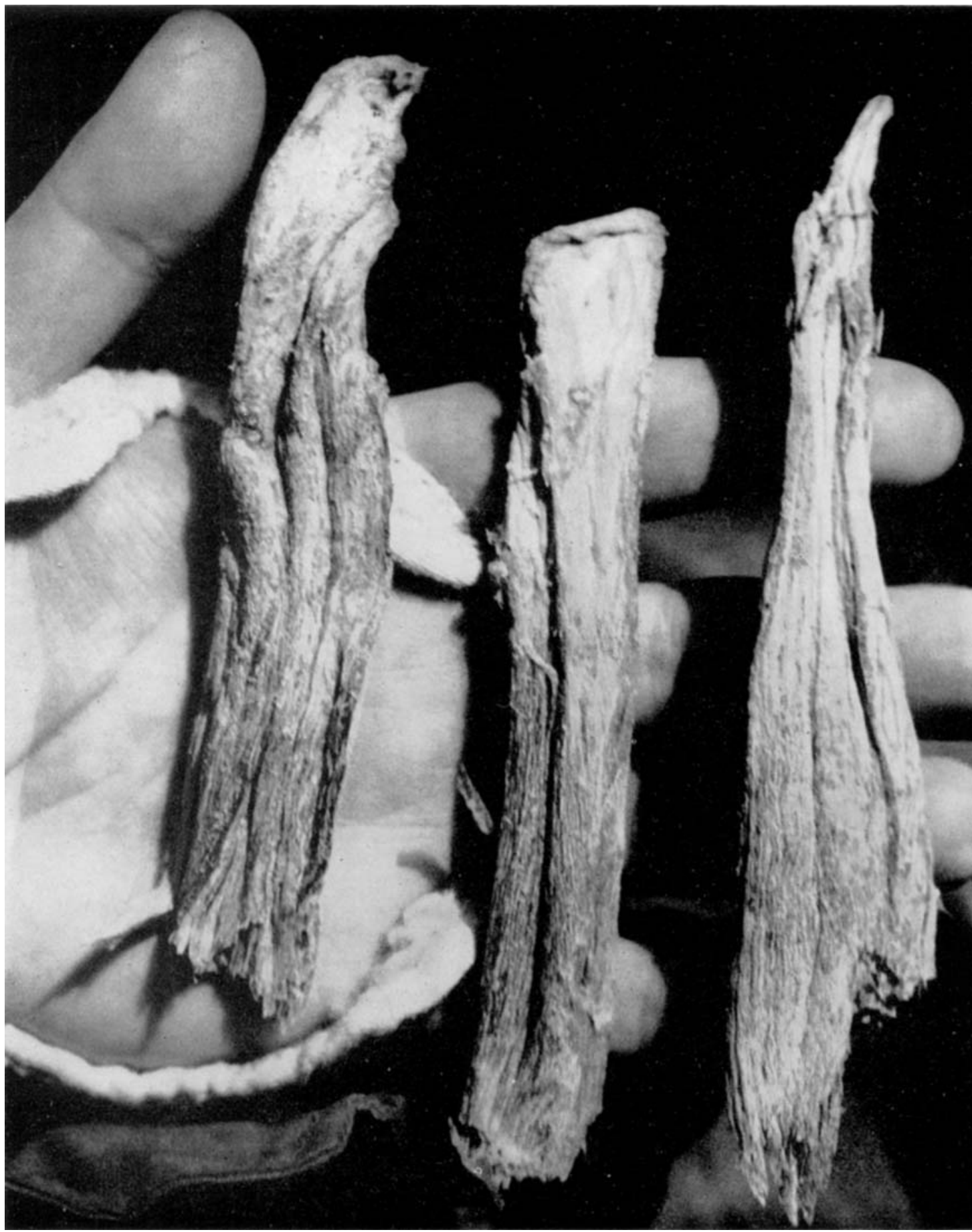

British Fournal of Nutrition, Vol. I I, No. I 